Historic, archived document

Do not assume content reflects current scientific knowledge, policies, or practices. 


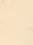




\section{FEDERAL-GRANT RESEARCH}

at the

STATE AGRICULTURAL

EXPERIMENT STATIONS

Projects on

ENTOMOLOGY AND ECONOMIC ZOOLOGI

Part 7, Section c

Agricultural Research Service

UNITED STATES DEPARTMENT OF AGRICULTURE 


\section{Compiled January 1958 by}

The State Experiment Stations Division, Agricultural Research Service, U.S. Department of Agriculture, Washington 25, D. C., for use of workers in agricultural research in the subjectmatter areas presented. For information on specific research projects write to the Director of the Station where the research is being conducted. 
FEDERAL-GRANT RESEARCH

at the

STATE AGRICULTURAL EXPERTMENT STATIONS

Profects on

ENTONOLOGY AND ECONOMIC ZOOLOGY

Section c: Miscellaneous Insects and Economic Zoology

Contents

Page

I. MISCELLAANEOUS INSECTS .............. 1

A. GENERAL ECONOMIC ENTOMOLOGI .......... 1

B. INSECT PESTS OF SEEDBEDS, CREENHOUSES AND MUSHROOMS. - 5

C. ORNAMENTAL PLANT INSECTS ............ 6

D. FOREST, FOREST PRODUCTS AND SHADE TREE INSECTS . . . 7

E. STORED CRAIN, HOUSEHOLD AND FOOD INSECTS ....... II

F. ARTHROPOD PESTS AND PARASITES OF MAN AND ANIMALS •. 15

G. PLANT DISEASE VECTORS ............ 20

H. BIOLOGICAL CONTROI OF INSECTS, MITES, ETC. ..... 23

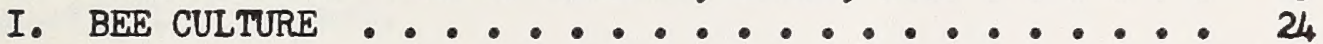

II. ECONOMIC ZOOLOGY ............. 26

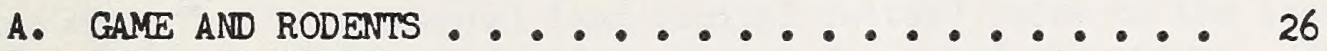

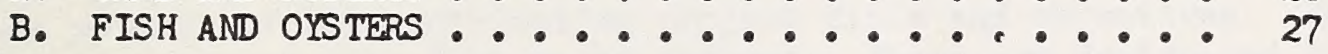

III. REGIONAL RESEARCH, INCLUDING STATES WITH CONTRIBUTING

PROJECTS ................... 30

IV. LIST OF SUBJECT-MATTER ARTA COMPILATIONS ... Attachment 

This compilation is one of a series providing information on State agricultural experiment station research supported by Federalgrant funds appropriated annually by Congress under authorization of the Hatch Act of 1887, as amended and approved Aug. 11, 1955, and Section 204(b) of the Agricultural Marketing Act of 1946. It is prepared for use by research workers in the subject-matter areas presented. Only that part of each State's research program supported by Federal-grant moneys is included.

In addition to the Federal-grant moneys, the State experiment stations receive some Federal support through cooperative agreements or contracts with the U. S. Department of Agriculture. Information on such research, along with other departrental research is available in the Central Project office, Agricultural Research Service.

A substantial part of each State agricultural experiment station's research is supported with moneys appropriated by the respective State or Territorial Leglslatures and through other forms of private and public financing. Informstion on current agricultural research at the stations which is not financed under the Federal-grant program or through USDA cooperation can be obtained from experiment station directors.

The information given in the series of Federal-grant compilations includes the title and objectives of each Federal-grant project pertaining to the subject given on the cover. The identification of each project gives the department(s) conducting the research, the station number of the project, and the number of the regional project if it is a contributing project.

Relevant regional projects, if any, appear at the end of the compilation. States having projects contributing to regional projects are indicated. The Roman numeral (and capital letter) refer to the location in the sumary of the contributing project title and objectives. The States are grouped into four major regions. These are designated NCNorth Central, NE-Northeastern, S-Suthern, and W-Western. The capital letter mM following the letters for the region indicates regional marketing projects. 



\section{MISCELLANEOUS INSECTS}

\section{A. General Economic Entomologr}

Ark.

Ecology and Control of Aphids. To study physical, chemical and biological factors affecting abundance of spinach aphid, turnip aphid, pea aphid, greenbug, and cotton aphid, including effect on populations of sub-lethal applications of insecticides, and effectiveness of various new and standard insecticides in control to be determined in conjunction with the ecological study, with emphasis on control at low temperatures. Ent. 186

Del.

Distribution and Abundance of Economic Insects and Their Damage to Crops in Delaware. (I) Increase yields and improve quality of crops by obtaining information for more effective insect control, for better detection of pest, for facilitating more accurate prediction of outbreaks and estimates of crop damage, and for indicating direction of future investigations. (2) Initiate preliminary emergency research on any species found to be of economic importance. Ent. 6-E

Del. The Application of Climatology to Delaware Agriculture. To learm (1) f requency distributions of rainfall, temperature and humidity for major crop areas of state and probabilities of occurrence of certain weather patterns likely to influence plant growth, disease, insect infestations and efficiency of crop treatments; (2) relationships between macroclimatic and microclimatic variables most influential in crop production; (3) learn relationship between available meteorological data and crop response, spread of plant diseases and severity of insect infestations; (4) influence of climatic conditions on crop growth, disease and insect infestations and efficiency of crop treatment.

Hort., Agron., P1. Path., Ent. 14-H (NE-35) Coop. USDC -WB

Hawail

The EDB Dip Process for Fresh Fruits and Vegetables. Analyze equipment needs for applying EDB Dip treatment to fresh fruits and vegetables. (2) Compare equipment needed for batch method and continuous method of treatment in terms of engineering and economic factors involved. (3) Design and construct pilot model processing unit.

Agr. Engin., Ent., P1. Path., Food \& Nutr. 742 
Hawaii

Investigations on the Biology and Control of Hawailan Mites. To (1) make a survey of mites of Hawali, to determine what species are present in the fauna, and which are to economic importance; (2) conduct studies on Hawalian mites with a view to developing knowledge of those characteristics of mite biologJ and population dynamics wich may be of value in developing or improving control; and (3) develop or improve methods of biological and chemical control suited to Hawailan conditions. Ent. 963 coop. ARS

Hawail

Blologies of Economically Important Insects in Hawail. To (1) increase the knowledge of the life histories of the pest insects found in Hawail and the beneficial species that prey on them; (2) build up a reference collection of immature stages and adults of pests and beneficial species that prey on them. Emphasis placed on species affecting health of man or animals and beneficial species that prey on pest species, (leaf mining insects, wood boring insects, insects attracted to carrion and filth and beneficial flies that prey on mealybugs and scale insects). Ent. 966

Idaho

Effect of Lrgus Spp. On Clover and Vegetable Seed Crops. To determine (1) if red, white Dutch, alsike, and ladino clovers and carrot and parsnip seed crops are affected by lygus bug feeding; (2) how injury is produced; (3) lygus bug population trends in these crops and populations needed to cause economic reductions in seed jields; and (4) critical period as to plant and insect development when control measures should be applied.

Ent. 227

Idaho The Biology of Mites that Feed on Crops and Other Plants and the Damage Caused in Idaho. To learn plant feeding mites wich occur in Idaho; host ranges of these plant-feeding mites; economically important species of plant-feeding mites. To study ecological factors affecting population trends of mites of economic importance and their life histories.

Ent. 252

Mass.

Climatology and Northeastern Agriculture. To learn (1) relation of area macroclimatological data to production and quality of agricultural crops of the state; (2) microclimatic conditions under which parasitic pathogens infect small fruit crops; (3) relation of climatic factors to insect pests, their distribution, survival, emergence, reproduction, and feeding rate. Agr. Engin., Met. 122 (NE-35) Coop. USDC-WB 
Minn.

A Study of Methods of Estimating Insect Abundance and Relating Population Density to Insect Damage. To(I) review and evaluate the methods now used to estimate insect population numbers; (2) study the comparative effectiveness of methods under a variety of environmental conditions; (3) determine effect of population size on efficiency of various metrods; and (4) evaluate the use of one or more sampling techniques in a study of population fluctuations of different types of insects over a sufficiently long period of time.

Ent., Econ. 2001. 1721

Mo.

Investigations and Control of the Codling Moth and Other Fruit and Vegetable Insects. To (1) develop more efficient spray program for control of insects and mites attacking tree fruits; (2) develop effective program to control insects and mites attacking small fruits; (3) study biology of arthropod pests of vegetable crops and develop better methods for their control; (4) study residues of chemicals applied to fruits and vegetables under field and laboratory conditions.

Ent. 31

Mo.

Further Studies on the Influence of the Different Elements and Plant Nutrients on the Well-Being and Fecundity of the House Cricket and other insects. To determine effect varying amounss of different soil minerals, minor elements and other nutrients, as laid down in plants, may have on rate of growth, longevity and reproductive potential of the house cricket and other insects when fed upon growing plants or parts of plants.

Ent. 74

Nebr. The Effects of Visible Spectrum Irradiation on Growth and Development in Several Species of Insects. (1) Measure effects of exposure by irradiation of delimited areas of the visible spectrum to German cockroach, cormon milkweed bug, and other selected insects; (2) Leam location of "receptor sites" within insect which are most probably altered as a result of irradiation;

(3) Identify particular hormone(s) involved and learn changes resulting from visible spectrum irradiation.

Ent. 569

Nebr.

Physiological Effects of 2 to 40 Megacycle Radio-Frequency Electric Fields on Insects. Learn (1) internal temporgtures within different areas of several species of insects immediately following exposure to high-frequency electric fields; (2) water loss in several species resulting from exposure to high-frequency electric fields and learn nature or source of loss; (3) possible damage to nerve tissue, especially the brain and ventral nerve cord, which may result from exposure to high-f requency electric fields. Ent. 578 Coop. ARS 
N.Y.

(Cornell)

N. C.

Oreg.

$\mathrm{Pa}$.

$\mathrm{Pa}$.

$\mathrm{Pa}$.

Ecological Study of the Regulation of Insect Numbers in a Community. (1) Study natural regulation of insect numbers in a community; (2) Leam effect of insecticides on this equilibrium in conmunity; (3) Use knowledge of biotic conmunities to improve methods of insect control; (4) Utilize population fluctuations of pest species.

Ent. 102

Studies on Heterozygosity, Heterosis, and Homeostasis in Drosophila. (I) To learn extent of degree of heterosis exhibited in crosses between and within a. homozygous genotypes; $\underline{b}$. geographical races, $\underline{c}$. sibling species, is a function of level of heterozygosity. (2) Learn extent that heterosis and developmental homeostasis are correlated in crosses. (3) Analyse consequences of selection for increased developmental homeostasis.

Ent. 72

Toxicological Studies on the Grar Garden Slug. To (I) determine effect of time, temperature, and moisture on residual life of metaldehyde; (2) improve formulation and application of metaldehyde; (3) investigate effects of metaldehyde and other chemicals on metaboIlsm of the slug; (4) screen chemicals as slug toxicants, and (5) make ecological studies on the slug.

Ent., Agr. Chem. 90-1

The Effects of Sound and Radio Waves on Insects and Rodents.

To (1) study factors influencing audiogenic seizures in rodents and

to explore possible uses of these reactions for rodent control; (2) explore possible use of sound waves, in sonic and ultrasonic ranges for repelling and killing insects; (3) find, if possible, auditory end-organs of household insects and study their properties, and (4) explore possible use of radio waves for destruction of insects and study physiological backgrounds of effects of radio waves on insects and fruits.

Zool., Ent. 1115 Coop. USAF-Hawali

An Analysis of the Correlations Between Polygene Combinations and the Resulting Expressions of Quantitative Characters. To determine (1) effects of diverse modes of breeding selection on gene systems controlling single and correlated quantitative characters, and (2) relationship between derived gene combinations and expressions of the characters they control, using Drosphilia melanogaster. Bot., PI. Path. 1249-A

Effect of Temperature on Insect Flight Mechanisms. Learn how temperature affects the speed, duration, and efficiency of flight. Zool., Ent. 1293 
S. C.

Identification and Distribution of Economic Insects in

South Carolina. (1) Obtain taxonomic and biological information on cutworms, army-worms, leafhoppers, bark beetles, etc., occurring in South Carolina. (2) Provide and maintain adequate identification of species of economic importance currently encountered. (3) Operate light traps in cooperation with ARS, and to correlate cullection with weather data. (4) Learn if it is possible to predict outbreaks of insects by means of trap light and fleld collections. (5) Prepare reports on seasonal and geographical data for publication. Ent. 102 Coop. ARS

W. Va. The Structure and Function of Specialized Tlssues in Insects. To make a basic study of anatomical features of insects, with particular emphasis on structure and functions of (1) sensory organs, especially the chemo-receptors involved in odor perception: (2) exoskeleton as related to protection against pathogens, microorganisms and insecticides; and (3) certain secretory organs.

P1. Path., Eint. 63

\section{B. Insect Pests of Seedbeds, Greenhouses and Mushrooms}

Miss.

Control of Arthropod Pests Attacking Greenhouse and Ornamental Plants. To determine (1) satisfactory insecticidal or cultural controls for the more important greenhouse and ornamental pests; (2) species and varietal tolerance of plants to effective insecticides; (3) value of plant nutrition and varietal resistance; and (4) most practical application equipment for various conditions. Ent. HH-5

Ohio

The Insect Phases of Greenhouse Vegetable Crop Production With Emphasis on Insect Pollinators as Well as Destructive Pests. (I) Obtain further information on biology and ecology of insect pest on vegetable crops grown in glasshouses; (2) Study: conditions responsible for development of resistant strains of mites and insects; (3) commercial control measures, and try to improve them; (4) Devise control measures for newly introduced or unusual pests; (5) methods to induce honey bees to pollinate greenhouse tomatoes efficientIy and consistently.

Ent. 25

Pa.

The Blologr and Control of Animal Pests Affecting Cultivated Mushrooms. To study the biology and most effective and economical measures for the control of the insects, mites, and nematodes which reduce the mushroom crop.

Zool., Ent. 714 
Pa.

An Investigation of Methods for Controlling Certain Insects and Mites Affecting Greenhouse Omamental and Vegetable Crops. To determine most effective and eccnomical measures for control of insects and mites causing injury to roses, chrysanthemms, snapdragons, camations, orchids, etc., as well as greenhouse tomatoes and cther food plants.

Zool., Ent. 957 Coop. ARS

\section{Ornamental Plant Insects}

Ind.

Insect Problems of Shade Trees, Shrubs, and Fruit Trees in the Nursery. To (I) develop a complete annotated bibllography of insects attacking nursery plantings; (2) determine the major pest problems occurring in Indiana; (3) investigate the Iffe history and habits of these major pests; (4) determine cultural and related practices in plantings and nurseries which may be factors in the presence or absence of pests, or which may affect their economic importance; and (5) to find chemical and/or mechanical means of completely controlling pests in nurseries so that pest free plants can be grown and shipped inter- or intra- state.

Ent. 477

N. J.

Systemlc Insecticides for the Control of Insects and Spider Mites Attacking Greenhouse Flowers, Ornamental Shruts and Flowers and hursery Plants. (I) Learn mechanics of action of systeric insecticides on ormamentals by determining: methods and rate of absorption thru roots, stems, seeds and forage; parts of plant to which systemics are translocated; length of effectiveness of systemics. Determine (2) types of insects and spider mites which are controllable by systemics; (3) economics of control by systemics as compared with previous control.

Ent. 213

R. I.

A Study of Insects and Mites Affecting Nursery Stock, Forest and Omamental Trees and Shrubs in Rhode Island. To (1) obtain essential information on seasonal occurrence and economic importance of insect and mite pests of nursery stock, ornamental trees and shrubs and forest trees; (2) investigate biology of insect and mite species when such information has not been heretofore reported; (3) determine relative effectiveness of various new synthetic organic chemicals as insecticides and acaracides for control of the species of economic importance; (4) investigate comparative vulnerability of insect and mite species in various stages of development to control measures, and (5) correlate appearance of most vulnerable stages in development of pest organisms with host plant development under R.I. conditions. Pl. Path., Ent. 6C4 
D. Forest, Forest Products and Shade Tree Insects

Ala.

Biolog and Control of Certain Insect Pests of Forests in Alabams. (1) Study and evaluate damage caused by more important forest insects in State. (2) Study certain phases of life histories and habits of important bark beetles and of pests of nurseries and seedlings. (3) Leam most practical method of controlling major insect pests of forest nurseries and established stands of seedlings. Zool., Ent. 111 (S-36) Coop. FS

Ala. Effect of Various Forest Situations and Practices on the Growth and Value of Forest Products and Returns from Forest Lands in Alabama. To (I) investigate factors that affect establishment, development, composition, and growth of forest stands and Fleld of products; (2) improve tree quality and rate of growth by selecting and developing superior seed sources; (3) develop improved methods of forest protection against fire, disease and insect attacks; and (4) evaluate economic aspects and applying accepted and new forest practices.

For. 411

Ala.

The Establishment, Growth and Yield of Forest Plantations in Alabama. To determine effect of certain site factors, especially soil, on the establishment, growth and yield of commercial tree species already planted and to develop specifications and instructions for planting such species under the site conditions exdsting in the State. Prevalence of insect damage will be included.

For. 509

Conn.

Larval Migration and Defoliation by the Grpsy Moth. Learn critical environmental factors affecting sypsy moth larval migrations and how these migrations are related to differences in defollation damage of resistant and susceptible forest sites. Ent. 314

Conn.

The Control of Vectors of Dutch EIm Disease. Improve efficiency of control of rectors of Dutch elm disease by development of more effective insecticides for application to (a) trees to be protected and (b) trees breeding vectors. Ent., P1. Path. 317 
Del.

Improvement of Measures for Control of Insects Attacking Farm Woodlands and Murseries. (1) Devise practicable ways for detecting presence, and for recording relative abundance of insect and allied pests damaging farm woodlands. (2) Learn effect of various ecological factors that might decrease or increase populations of any particular species.

Ent. 3-E

Hawail Biology, Ecology, and Control of Termites. To learn (1) how colonies of territes become established in buildings; (2) relationship of soil type and molsture to distribution and abundance of subterranean termites; (3) rate of buildup of termite colonies originating from individual pairs; (4) effectiveness of different chemicals for use in eliminating existing termite colonies and prevention of subsequent termite entry or attack; (5) resistance of chemically treated and untreated products to termite attack; (6) effectiveness of chemicals applied as dusts in termite galleries in destroying termite colonies.

Ent. 965

Iowa

The Study of Oak Wilt Caused by Endoconidiophore Fagacearum Bretz. To (1) develop better understanding of relationships between causal organisms and its host; (2) determine more about characteristics of causal organism. (3) determine how the disease organism travels long distances to cause new infection centers; (4) develop better methods for oak wilt control under forest conditions; and (5) develop methods for oak wilt control under recreational and ornamental planting conditions.

Ent., Bot., PI. Path., Zool. 1047 (NC-22)

Kans. Insect Vectors of Plant Diseases. To study (1) nature and extent of injury caused by toxdcogenic insects; (2) ecology and habits of known vectors; (3) Search for new vectors; (4) Study chemical and other control methods of rectors.

Ent., Bot., P1. Path. 475

Kans.

Insects Attacking Shade Trees and Ornamental PIants. Obtain fundamental information on biology, ocology, distribution, and habits of insects; (2) Study control measures; (3) Study relationship between drought, insects populations, and damage in shade trees and ornamentals.

Ent., Hort. 477 
Maine Wood Borers in Forest Products. To (1) determine species of borers in damaging cut logs and other forest products, and relative importance of species found; (2) work out life cycles and habits, for Maine, of species found to be most destructive; and (3) use acquired knowledge of life cycles as basis for research tests to develop effective controls for wood borers in Maine.

For. 79

Mass.

Insects Concerned in the Dispersal of Dutch EIn Disease, With Special Reference to the Native (American) Elm Bark Beetle, Hylurgopinus Rufipes (Eich.) To (1) study habits and distribution of Helurgopinus rufipes (Eich.), Scolytus multistriatus Marsham and other insects which may be vectors of Dutch elm disease fungus, Ceratostomella ulmi (Schwarz) Buisman, especially correlation between timing of their feeding habits and seasonal development of host trees when fungus invasion is most likely, so insecticides may be applied at most appropriate time; (2) test new insecticides for elm bark beetle control; (3) experiment with hydraulic sprayers and mist blowers and, when possible, helicopters and other new spraying equipment to learn effectiveness in covering tall trees with insecticides; (4) study effectiveness of most promising insecticldes and spraying equipment in actually preventing elm trees from becoming infected with Dutch elm disease fungus over a period of 5 to 10 years; and (5) when necessar, and in cooperation with other departments, study toxicity to cattle of any insecticide that seems imminent of adoption by the public for Dutch elm disease control.

Ent. 53

Mass.

Materials and Methods Which Promise Value in Control of Insects and Mites on Ornamental Shrubs and Shade and Forest Trees. Study value of newer insecticides and miticides, and applications for control of insects and mites on ornamentals and forest trees.

Ent. 56

Mass. Use of Insecticides to Prevent Borer Damage to Unseasoned Logs. Learn effectiveness of various insecticides and methods of application in preventing damage by wood boring insects to unseasoned logs and lumber.

Ent. 59

Mass.

A Method to Minimize the Adverse Effect Upon Tree Form of Attack by the White Pine Weevil. To compare (1) removal of all but one lateral branch in second-irom-the-top whorl of branches with (2) retention of all laterals in this same whorl to learn effect of treatment (1) on subsequent development and straightness of a substitute main leader to take place of normal leader destrojed artificially to simulate attack by white pine weevil.

For. 74 
Minn. Insect Pests for Forest and Shade Trees.--A. Forest Management in Relation to Insect Pests of Plantations.--B. Epidemiology and Control of Insect Outbreaks in Forests and on Shade Trees.-C. Minnesota Forest Insect Surver. To (1) facilltate prediction of tree insect outbreaks before they develop to the point where it is too late to attempt control; (2) provide basic understanding of natural control agencies operating to terminate outbreaks and sometimes prevent them; (3) develop forest management procedures to reduce or ellminate losses resulting from insect damage; and (4) explore field of chemical control, both means of applying poisons to trees and use of newly developed insecticides. Ent., Econ. 20ol. 1706

Minn. A Study of the Effect of the Source of Seed Upon the Growth, Development, and Habits of Native Tree Species.--A. A Study of the Effect of Source of Seed and the Influence of Insects Upon the Growth, Development, and Habits of Jack Pine (Pinus Banksiana Lamb.) To study (I) effect of climatic conditions upon growth, development and hardiness of jack pine from various portions of its range; (2) effect of form of parent tree upon the progeny; (3) variations in seed value from different portions of trees range; (4) whether the characteristics of opening cones annually on trees is inherited; and (5) influence of insects, such as tip moth, pitch nodule makers, sawily, midges and others, on form and development of tree and determine methods of control.

For. 1902

Miss. Biology and Control of Certain Insects Affecting Forest Trees and Unflnished Forest Products in Mississippi. (I) Evaluate damage caused by insects previously listed; (2) Study life histories and habits of insects listed; and (3) effect of environmental factors on biology and damage caused by insects; (4) Develop control measures for these specles applicable to nurseries, forests, woodlots, and unfinished wood products.

$$
\text { Zool., Ent. HH-2, RRFH2 (S-36) Coop. FS }
$$

Mo.

Taxonomy and Biology of Insects Attacking Acorns in Missouri. (1) Conduct systematic study of insects attacking acorns with emphasis on various species of nut curculios; (2) Investigate blology and ecology of insects attacking acorns.

Ent. 294

Mo.

The Blology and Control of Carpenterworms and Associated Borers In Missouri. Study the biology, taxonomy, ecology, and control of carpenterworms and assoclated borers and evaluate their importance as enemies of hardwoods.

Ent. 321 Coop. FS 
P. R.

W. Va.

Ariz.

Ark.

Chemical Characterization of the Termite-Repellent Substance in West Indian Kahogany Wood (Swietenia Mahogany). To characterize chemically the substance responsible for termiterepellent activity of mahogany wood.

Mutr., Ent., Biochem., Med. 83

Factors Affecting Natural Regeneration in Upland Oak Types. To (1) test various types of reproduction cuttings in evenaged and unevenaged upland oak stands on various sites, in order to determine which methods of cutting are most applicable to obtaining oak regeneration in these forest types; (2) determine most important species of harmful and beneficial insects affecting natural regeneration of upland oaks; and ascertain nature of some of their ecological relationships to the forest; and (3) determine effect and relative importance of rodents and animals other than insects, depth of litter, and compactness of surface soil on viability and germination of acorns.

For., PI. Path. 67

\section{E. Stored Grain, Household and Food Insects}

The Biology and Food Preferences of the Khapra Beetle as Ther Relate to Grain Marketability. Obtain basic information on biology, ecology, and economic injury of khapra beetle under conditions prevailing in the southwest.

Ent., Agron. 389 (WM-16) Coop. AMS

Improved Marketing of Grains Through Insect Control. To (1) investigate kinds of insects damaging cash grain in farm storage and evaluate the effects on quality and market value of the grain; (2) determine sources of infestations and factors favoring population increases and correlate cost of controlling these factors; (3) determine importance of varlous species and evaluate factors contributing to their development; and (4) determine better methods for direct and indirect controls and evaluate these in terms of cost, change in quality, and market value.

Ent., Econ., Sociol. 391 

hensive study of Khapra beetle, including facets of its biology, ecology, normal and abnormal physiology and devise control measures for protection of stored products. (1) Biologr. Relation of temperature to development of eggs, larvae, pupae and adults-life history stidies of temperatures from 50-1100F, investigate thermal death point, effects of low temperatures above and below freezing; effect of light conditions and intensities on life cycle at various temperatures; continue studies on food preferences, length of survival of various life-stages in absence of food; factors influencing oriposition sites of females. (2) Physiologr. Investigations of possible diapause in overwintering larvae, moulting and metamorphosis, nutrition of larvae to gain insight into food range and limitations thereof. (3) Control. Studies will be conducted to determine effectiveness of various chemical controls as: studies with fumlgants, studies with contact insecticides, studies with stomach poison insecticides, studies with attractants and repellents-with physical agents, mechanical barriers, trapping devices, inert materials as deterrents, and with radiant energy.

Ent. 1671 (WM-16) Coop. AMS

Col0. Maintaining Marketability of Wheat in Farm Storage and Country Elevators Through the Control of Insects. To (I) obtain technical data on distribution, infestation, reservoirs, and conditions favoring high population densities of principal species of insects affecting marketability of wheat on farm and in country elevators; (2) determine value of varlous commercial protectants and fumigants to improve marketability of grain under farm storage; (3) study role of lesser grain borer as a factor in lowering quality and marketability of wheat; and (4) determine effect of insect damage in terms of economic loss to farmers and estimate increased returns from use of protective treatments. Ent. 217 (WM-16)

Del.

Biology and Control of the Clover Mite, Bryobia Praetiosa Koch, in Delaware. (I) Fill in obscure portions of life history of mite as overwintering stages and habitat, favorite host plants for feeding and egg deposition and length of various stages. (2) Test by 1ab. and field methods effectiveness of recently-developed miticides and re-evaluate under local conditions the older miticides.

Ent. 7-E 
Idaho Bionomics of Stored Grain Insects Affecting the Marketabilit of Grain in Storage. To (1) determine stored grain insects affecting marketability of grain and economic importance in farm and elevator storage; (2) determine factors affecting insect populations in farm and elevator grain storage; (3) study life histories of more important stored-grain pests under conditions existing in farm and elevator storage especially as they relate to control of such insects in grain for market; and (4) determine economic significance of stored-grain insect populations.

Ent. 286 (WM-16) Coop. AMS

Iowa

Entomological Problems Involved in Corn and Other Field Grain Storage. To (1) test insecticides against corn and feed-grain pests under conditions of temperature, humidity, and other factors prevailing in practical storage; (2) discover more effective and cheaper fumigants and easier and safer methods of using them; (3) study effect of size, shape, construction, and ventilation of storage structures on dynamics of populations of stored grain pests; and (4) study inter-relations between insect infestation in stored grain, heat and moisture production, and prevalence of and spoilage caused by fungi.

Zool., Ent. 1257

Kans.

Insects Affecting Stored Grain and Milled Grain Products. To (1) study biology and behavior of grain and milled grain products insects; (2) develop methods for distinguishing insect fragments in milled grain products: (3) determine effects of new insecticides on grain infesting insects, and (4) study insect problems in farm stored grain.

Ent. 322

Ia.

Stored Grain Insects With Special Emphasis on Those Infesting Rice, Especially the Rice Weevil. To perfect effective, practical and economical control measures suitable for storage conditions and requirements in La., embracing: 1. biology of rice weevil and other species; 2. ecological factors affecting species as pests; 3. seasonal habits; 4. varietal resistance; 5. control. Agron., Ent. 827 Coop. AMS

Minn.

Storage of Grain in Various Atmospheres in Sealed Bins. To learn effects of various atmospheres on the microbiological, entomological, and bio-chemical factors that influence the quality of stored grains, especially wheat, corn and soybeans.

Ag. Blochem. 1517 
Minn. Effect of the Association of Molds and Insects on the Keeping Quality of Stored Grain. To learn if the development of insects within stored grain bulks is associated with, or contributes to, growth of storage molds that are known to lead to heating and other spoilage of stored grains. Ent. 1730

Miss. Control of Insect Pests of Stored Corn and Small Grain. To leam (I) necessary modifications of steel and other type bins used in Mississippi for the efficient use of fumigants; (2) rates and frequency of application of fumigants needed in properly prepared bins necessary to avoid being graded as 'weevily'; (3) efficiency of 'grain protectants' for the control of different species of insects on clean grain; (4) effect of foreign matter and molsture content of grain (surface and beneath surface) on the control obtained from use of 'grain protectants' and fumigants; (5) importance of field infestations and possibly of farm management being used to reduce the infestations; (6) value of chemicals other than those tested which have characteristics that suggest a possible means of control of the rice weevil on corn stored in the shuck; and (7) differences in the rate of increase of rice weevil populations in those corn single crosses which have possibilities of being used for the production of hybrid seed. Ent. HH-7

N. Y. Studies on the Biology and Control of Household and Structural

(Cornell) Insect Pests. Study biolog of cluster fly, etc., and leam breeding place, its natural controlling factors, and how its activities can be controlled. Ent. 99

N. C. The Control of Insects Affecting Stored Grain. To learn (1) changes in grain grade and other measures of quality with respect to levels of population of storage insects; (2) resistance of certain varieties to storage insect attack and causes responsible for resistance; (3) relationship between moth and weevil development in stored grain as affected by time of planting and harrest; (4) best fumigants and other insecticides for control of stored grain pest, with especial attention to Angoumois grain moth and rice weevil.

Ent., Agron., Chem., HM-14

N. Dak.

Insect and Rodent Contamination of Cereal Grains. Learn ( 1 ) kind, degree, time, and place of contamination of wheat and barley that occurs between standing crop, and freight car, particularly the on-farm contamination; (2) how contamination is related to harvesting methods and storage facilities used in different crop production area of state; (3) factors associated with presence of contamination and variability of these factors in different ecological situations. Ent. 5-6 
Oreg. Ecology and Biology of Stored Grain Pests in Areas with a Coastal Climate in Relation to the Development of Infestations Affecting the Marketability of Grain. To (1) determine nature, extent, and species involved in stored grain insect problem in Western Oregon, which area would typify a marine west-coast type of climate; (2) acquire biological and ecological data on insect infestations in stored grain in western Oregon which differ in type or intensity from infestations in other areas; and (3) use information from foregoing sources to prevent or control infestation in western Oregon and similar areas. Ent. 99-5 (WM-16)

S. C. Control of the Rice Weevil and Associated Insects in FarmStored Corn and in Food Products Made from Such Grain. To (I) find an economical, practical method of controlling rice weevil and associated insects in farm-stored corn; (2) control insects in farra-stored corn intended for human consumption; and (3) investigate simple, practical procedures in producing clean corn meal from corn avallable in the state. Ent. 104

Wash. Control of Insect Pests of Stored Grain. To (1) evaluate chemical grain protectants for control of wide range of stored grain insect pests which occur in the Pacific Northwest; (2) evaluate insecticides as residual sprays on walls of storage facilities; (3) evaluate grain losses incurred by each of important grain infesting species; (4) conduct intensive survey to trace seasonal development of insect population in storage facilities, to evaluate role of sanitation practices, and attempt to correlate insect infestations with type of storage unit construction; and (5) conduct other pertinent studies on stored grain insects.

Ent. 1127 (WM-16)

\section{F. Arthropod Pests and Parasites of Man and Animals}

Ark.

Ecological Factors Favoring Abundance: The Dispersal; and Methods of Control of the Lone Star Tick, A. Americanum In Arkansas. To develop a practical, thorough method of protecting man and his animals from attack by this tick. Ent. 261

Ark.

Cattle Grub Control. Develop a more satisfactory method of controlling cattle grub with particular emphasis on controlling the adult or newly hatched larvae.

Ent. 432 
Ark. Control of Biting Flies Attacking Cattle. (1) Develop an oconomically feasible control for horse fly, deer flies, stable flies, and southern buffalo gnat. (2) Learn breeding areas, habits, and If e and seasonal history of southern buffalo gmat. (3) Develop a useful survey technique for predicting outbreaks of southern buffalo gnat.

Ent. 433

Ark. Biological and Toxicological Studies of the Horn Fly. To leam (1) Iife cycle of horn fly and factors influencing duration of stages; (2) lethal dose for adults after repeated exposure of a controlled population to insecticidal selection pressure. Ent. 459

Del. Mosquito Investigations: Flight Range Studies of Pest Mosquitoes. Investigate flight range of pest mosquitoes in Delaware.

Ent. 2-E Coop. USDI-IWS

Kу•

Biology and Control of Horseflies Affecting Livestock. To (1) develop insecticides or repellents that can be safely applied to horses, mules, and cattle for control of adult flies of Tabanus and Chrysops, (2) study use of attrahents for trapping houseflies, and (3) work out life histories and distribution of injurious species in various parts of the state.

Ent., Bot. 456

La. Biology and Control of Insects, Ticks and Mites Which Attack Livestock and Poultry. (1) Obtain complete information on biology and distribution of livestock pests; (2) Evaluate damage caused by each species; (3) Develop effective and economical control measures for the important pests.

Ent. 905

Minn. A Study of the Ecology and Control of the Pest Mosquitoes of Northern Minnesota. To (I) conduct a general survey of mosquitoes and mosquito breeding places to determine which localities and species are most important; (2) make detailed study of the life cycle and breeding places of the species found to create the greatest nuisance; (3) try to classify breeding places by means of obvious biological indicators so potential sources of large mosquito populations can be anticipated and control campaigns carried out intelligently; (4) study dispersion patterns of princi$\mathrm{pal}$ species to discover extent of areas which might be involved if control programs are to be effective.

Ent., Zool. 1731 
Miss. Biology and Control of Insects Affecting Dairy and Beef Cattle. Cattle Iice--to investigate the efficiency of insect1cidally impregnated back rubbers for lice control on cattle. Horn flies-to (1) improve the efficiency of back rubbers and remove hazards resulting from the use of a too harmful chemical on these devices for horn fly control on cattle; (2) determine the favorable conditions, such as those of weatler, affecting a large horn fly population build-up; and (3) determine if horn flies are becoming resistant to chlorinated hydrocarbons and organic phosphate insecticides; Horse and deer flies--To evaluate the effectiveness of promising insecticides for horse and deer fly control, and investigate the possible use of repellents as a means of protecting livestock from the attacks of these pests. Cattle grubs--to (I) investigate host resistance among cattle to grub infestations; and (2) develop a technique for infesting bull calves with young larvae dissected from slaughtered animals, as systemic research for cattle grub control would proceed much more rapidly if a larvae-infesting method of calves would be perfected. Ent. HH-6

Mo.

Biological Investigations and Control of the Stable Fly, Horse Flles, and House Flies As Animal Pests. Investigation of Improved Methods of Control of Mange Mites, Cattle Grubs and Screw Worns. To determine (1) role natural competitive factors play in control or lack of control of house flies with baits and balted sprays; (2) more attractive materials for use in house fly balts: (3) relative efficiency of Diazinon as residual spray and Diazinon as baited spray or dust in house fly control; and (4) under what pasture and herd conditions micro-sprayers will operate and control horse and horn flies most efficiently and economically. Ent. 46

Mont. Biology and Control of Mosquitoes in Montana. To (1) study biology, habits, and distribution of mosquito species in Montana as related to their enviromment; and (2) use this information in finding economical methods for controlling mosquitoes where they present $a$ health and nuisance problem to man and domestic animals. Zool., Ent. 44 M.S. 886 Coop. HEW-USPHS

Nebr. Biology, Ecology and Control of the Stable FIy. To determine biology and ecology of stable fly, a pest of Iivestock and develop more practical measures for its control. Ent. 442 
N. J.

Mosquitoes in Relation to Agricultural Production and Veterinary Sclence. (1) Evaluate effect of mosquitoes on production of meat, milk, and animal products in certain parts of state and development of procedures for reducing economic loss; (2) Define importance of mosquitoes in management of equines in state and research on systemic and surface repellents for use with animals; (3) Clarify role of mosquitoes in transmission of virus and protozoan diseases of domestic birds and animals to learn reservoirs of such diseases.

Ent. 212 Coop. HEW-USPHS

Okla.

The Biology and Control of Vectors of Anaplasmosis. To develop and demonstrate more effective means of controling the vectors of anaplasmosis and to intensively study the biologies of these arthropods so that the most effective time for control may be found.

Vet. 312 coop. ARS

Okla. The Control of External Parasites. To (1) develop effective repellents to protect animals from external parasites, especially those with resistance to common toxicants; (2) evaluate effectiveness and hazards of new chemicals as pest toxicants; (3) determine best methods to apply insecticides to animals, especially automatic sprayers, rubbing posts and treadle machines; (4) obtain biological data to assist in above objectives; and (5) obtain adequate data indicating gains to be expected from parasite control. Anim. Husb. 593

Pa.

Insect Pests of Livestock. To study (1) life history patterns of insects associated with livestock and learn which stage of development is most susceptible to control; (2) rate at which insect pests of livestock develop resistance to insecticides; (3) new insecticides and techniques as to application for control and effect of such procedures on animals.

Zool., Ent. 1261

S. C.

Insects Affecting Man and Animals. to (1) compare repellents against several varieties of biting flies of dairy and beef cattle; (2) determine best methods of applying repellents and insectleides with emphasis on automatic treadle sprayers and back rubbers; (3) test the better repellents against horseflies and deerflies in parts of S. C. where they occur in large numbers, causing much annoyance to animals; (4) test insecticides using residual spray and bait methods for housefly control in dairy barns and other bulldings; (5) determine most effective materials and methods of application of controlling ticks and chiggers of man and animals; and (6) test insecticides and methods of application for control of lice and grubs on cattle.

Ent., Zool. 65 
External Parasites of Poultry, Their Biology, Distribution and Control. (I) Survey external parasites present in state, and Ieam distribution of each. Study: (2) biology of certain species and relate this to control practices; (3) effectiveness of newer insecticides; (4) effectiveness of control by insecticides used as systemics; (5) toxicity of newer insecticides to various classes of poultry.

Ent., Zool., Poult. 134 Coop. ARS

Va.

Bionomics and Control of Certain Insect Pests of Cattle. (1) obtain information on life history and habits of common species of cattle lice in state and evaluate methods and materials for their control; (2) Learn most economical and effective control of house fly in dairy barns; (3) Evaluate methods and materials for control of blood-sucking flies; (4) Study life history and habits of cattle grub and evaluate most effective control; (5) Evaluate losses caused by these insects in Virginia.

Ent. 86070

Va.

The Biology and Control of Certain Insects Associated with Poultry. (1) Obtain information on life histories, distribution and habits of more important insects and mites associated with poultry in Virginia; (2) Apply biological information to development of improved control techniques; (3) Evaluate new insecticides for control power; (4) Conduct studies basic to use of systemic insecticides for control of arthropods.

Ent. 86086

W. Va.

Arthropods Affecting Livestock in West Virginia--Their Distribution and Control. To conduct a survey and collecting program to determine kinds, distribution, incidence and economic importance of pests of livestock in the state.

Ent., Anim. Husb., Dairy Husb., Bact. 79

Wyo.

Cattle Lice Control.

(1) Find ovicidal compounds that might be used in combination with chlorinated insecticides for control. (2 \& 3) Learn effectiveness of power-dusting as a control method and effectiveness of rubbing devices for lice control on large free-ranging herds.

Ent., Parasitol. 591

Wyo.

Mosquito Control in Irrigated Areas. Leam (1) average percentage of total irrigated area that remains inundated long enough to produce mosquitoes; (2) minimum effective dosage per acre of heptachlor granular as a larvicide and pre-flood treatment and of Dylox granular and soluble powder as larvicide; (3) utility of granular formulation and capsuled insecticide for hand application; (4) by trials on a large area, if warranted, if the inhabitants (with initial professional help) would be able to conduct successful control programs.

Ent., Parasitol. 687 


\section{G. Plant Disease Vectors}

Calif.

Insect Vectors of Plant Viruses.

(1) Correlate economic losses resulting from aster yellows with distribution of strains of virus in the State; isolate strains and learn host ranges and rector relationships. (2) Maintain cross protection tests with strains collected to learn degree of protection occurring in host plants and leafhopper vectors. (3) Compare incubation perfods and retention patterns of virus strains in different species of leafhoppers following controlled acquisition feeding period of varying lengths. (4) Study transmission of viruses by aphids, beetles, and leafhoppers. (5) Compare host ranges and symptoms induced by viruses. Ent., Parasitol. 657

Caisf.

Aphids As Vectors of Field Crop Virus Diseases. Learn and clarify the vector-vimus-host plant relationships existing among the aphid-borne virus diseases of various crop plants. Ent., PI. Path., Parasitol. 1365A

Galif.

Insect Vectors and Their Relation to Virus Diseases of Deciduous Fruits and Berries in California. To (1) establish identity of vectors of the diseases, (2) study life history and host plants of vectors, (3) investigate host range of viruses when transmitted by insects, and (4) investigate virus vector relationships.

Ent., Parasitol. 1365-B

Calif.

Insect Vectors and Their Relation to Virus Diseases of Ornamental Plants. To (I) study insect vectors, properties, host range and symptoms of nasturtium viruses in order to distinguish them and evaluate their respective incidence and importance and (2) determine the insect vector of orchid mosaic virus, properties of the virus and its relation to such vectors. Ent., Parasitol. 1365-C

Insect Transmission of the Orange Tree Quick Deciline. To investigate (1) identity of vector as determined by transmission tests, (2) occurrence and abundance of vector in various citrusgrowing areas of the state, (3) vector's seasonal life history and identity of host plants, and (4) effectiveness of insecticidal control of vector in reducing spread of the disease.

Ent. 1370 
Ky.

Mich.

Transmission of Virus Diseases of Field Crops by Insects and Mites. To learn (I) which insects and mites transmit virus diseases of field crops; (2) entomological factors influencing virus transmission of these diseases; (3) host naturally infected by selected viruses transmitted by insects or mites. (4) Find new methods and improve and simplify present methods of achieving above objectives.

Ent., Bot., Agron. 1010

Insect Vectors of Crop Plant Diseases. To (1) determine insect vectors of aster yellows on potatoes, lettuce, carrots, gladiolus, etc.; (2) study bionomics of species concerned; including life history, migration, food plants, ecology, and control; (3) study mechanics of disease transmission by species under study; (4) make inoculation experiments with various virus diseases, using accurately determined species or races of insects; and (5) by mass transfers of infected insects to non-infected plants of the sane and of different species. Ent. 78

Mont.

Viroses of Sweet and Sour Cherries in Montana. To study the occurrence, symptoms, spread and control of viroses of sweet and sour cherries in Montana, especially little cherry and bud and scion perpetuated diseases.

Bot. \& Bact. MS 830

Webr.

Relation of Insects to the Transmission and Epidemiology of Plant Diseases. To (1) ascertain role of insects in transmitting Viruses and other disease producing entities of plants; (2) determine basic insect plant pathogen relationships. and (3) develop control measures, including use of insecticides, cultural practices and any other means effective in reducing build up of epidemics due to insect activities. Ent., PI. Path. 474

N. Y. Virus and Virus-ifike Diseases of Thee Fruit.--5. Transinission

(CornelI) of Viruses that Affect Tree Fruits, and Their Insect Vectors. (1) Find and identify vector(s) of esch of several important vimuses crusing diseases in stone fruits. Study insects to learm means $\mathrm{CI}$ application of control measures. Study insect transmission wich provides means of separating virus complexes. Ent., P1. Path., Pomol. 134-5 (NE-14)

Ohio

A Study of Possible Vectors of the Oak Wilt Disease Organism. To (I) ascertain the species of insects, if any, that are attracted to Chalaramats; (2) if suspected vectors are found, determine if they carry the oak wilt organism either within or upon their bodies: and (3) find if they can transmit the organisms to healthy oaks. Ent., 96-3 (NC-22) 
Oreg. Virous and Similar Diseases of Orchard Trees. To determine identity and distribution of virous and virous-like diseases of orchard trees including insect vectors.

Ent., Pl. Path. 44

Oreg. Determination of Insect Vectors of Peach Ring Spot and Associated Viruses. To (I) determine the vector(s) responsible for transmission of peach ring spot and associated viruses; and (2) use the vector $(s)$ when found, to isolate components of the complex and maintain these cultures for use by various cooperating plant pathologists and entomologists of the Western Region. Ent., P1. Path. 344 (W-22)

Oreg. Studies on the Relationship of the Mite Pediculopsis Graminum Reut. To Silver Top Disease in Oregon Grasses. (1) Study biology of Pediculopsis graminum Reut. and its relation to Fusarium poae. (2) Learn how other arthropods may be involved in mite-disease complex. (3) Test various miticides and insecticides for control of $\mathrm{P}$. graminum.

Ent., Bot. and PI., Path. 291

Texas The Cause and Control of "Pimples" A Serious Defect of Water melons. To (1) establish cause of defect of maturing watermelons known as "pimples", "sand bumps", or "water bumps"; (2) determine how it spreads, and in what form and where inciting agent exists in winter; (3) learn what other plants, harbor causal agent or show related condition; and (4) develop control measures.

P1. Physiol. and Path., Ent., Hort. 904

The Symbiotic Relationships Between Microorganisus and Insect Vectors of Plant Diseases. To investigate insect transmission of plant diseases as a distinct biological phenomenon fundamental to general sciences of plant pathology and entomology, especially to determine for cucumber beetles; (1) how cucumber wilt bacterium survives in the insect body, (2) if symbiosis is involved, (3) if bacteria are transmitted thru eggs to larvae, (4) if bacteria survive pupal period, and (5) if physiological condition or physical environment of beetles influence interrelations of vector and bacterium.

Pl. Path. 62

W. $\nabla a$.

Virus Diseases of Sour Cherry and Other Stone Fruits.--(1-3) To learn (1) rate of spread of cherry virus diseases, (2) method of spread of stone fruit viruses in general with reference to possible insect vectors of cherry yellows and ringspot, (3) effect on yield and tree growth caused by viruses of sour cherry. (4) Attempt to locate virus-free sources of Mazzard cherry seed for commercial propagation.

P1. Path. 89 (NE-14) 
Wis.

The Relation of Leafhoppers and Aphids to the Transmission of Vegetable Crop Viruses. Learn species responsible for dissemination of truck crop viruses and their importance in epidemiology of diseases under field conditions. Habits, host relations, migration, and reducing insect vectors by insecticidal, biological, and cultural means will be studied. Lab. and greenhouse studies will show basic factors involved in vector-virus-plant relationships: as acquisition sequence; inoculation, retention, and latent periods, and vector feeding habits. Ent., Hort., P1. Patr. 725

\section{H. Biological Control of Insects, Mites, etc.}

Ariz.

Insect Parasites and Predators of Insect Pests of Arizona Crops. (1) Learn: identity, distribution, and relative abundance of insects belonging to families generally recognized as containing species parasitic or predatory on other insects; and where needed descriptive, biological, and ecological information is lacking; and suggest where future work might be profitably done. (2) Evaluate effectiveness of the more common species of insect parasites and predators as control agents. Make related biological and ecological observations for more detailed work.

Ent. $4 \mathrm{OL}_{4}$

Ark. Abundance of Corn Earworm in Relation to Hosts, Biological Control Agents and Physical Environment. (1) Seek causes of fluctuation in field populations of corn earworm in corn and in other available hosts. (2) Study effect of climate. (3) Analyze the effect of predators, parasites, and diseases and further investigate host abundance to seasonal population fluctuations. Ent. 450

Calif.

The Nature and Properties of Insect Viruses.--Investigate: the possibilities of in vitro cultivation of insect viruses, by means of tissue and cell culture; phenomenon of virus infection sensu stricto and particularly the fate of granulosis and polyhedrosis virus after ingestion or intrahoemocoelic inoculation, in the period preceding the formation of inclusion bodies; the chemical and physical properties of insect viruses.

Biol. Control 1333

Calif.

The Nature of Infectious Processes in Insects. To increase store of basic and fundamental knowledge relating to cause, symptomatology, pathogenesis, pathology, and epizootiology of the infectious diseases of insects. Biol. Control 1484 Coop. HEW-USPHS 
Calif. Evaluation of the Effectiveness of Native Natural Enemies of the Spotted Alfalfa Aphid and Other Aphids. Learn (1) role that various natural enemies play in control of spotted alfalfa aphid and other aphids; (2) influence of environmental conditions on native natural enemies.

Biol. Control 1748

Hawail Infectious Diseases of Insects in Hawail and the Use of Micro-Organisms For the Control of Insect Pests. To learn the possibilities of using micro-organisms to combat insect pests and test their effectireness in the field. Ent. 962 coop. ARS

Ind. The Effect of Fungus Products on Arthropods. (1) Search among products of microorganisms for compounds causing biological response in arthropods as demonstrated by attraction, repellency, or toxic proferties. (2) Learn mode of action and properties of compounds causing biological responses in arthropods. (3) Develop techniques for practical application of any potentially useful compounds discovered.

Ent., Bot. and PI. Path. 906

Maine

The Influence of Modified Spray Programs on Parasites And Predators of Orchard Insect Pests in Maine. Loarn (1) extent, occurrence and importance of parasit1c-predatory fauna; (2) species which might effect orchard insect pest control under state conditions, and degree of control expected; (3) length of time that must pass before these biological agents effect control of pests in an orchard removed from a standard control practice and placed on a modifled program, and extent of damage by pests until they are brought under control; (4) factors promoting an increase, and maintaining a balance between agents and hosts.

Ent. 108

\section{Bee Culture}

Ariz. Pollen Substitute for Honerbees. To produce an economical substitute for pollen fraction of diet of honeybees.

Pl. Physiol. 382

Fla.

An Economic Analysis of the Florlda Honey Industry. To make analysis in respect to: market flow over time, market place distribution, costs and factors affecting costs of packing honey.

Agr.Econ. 791 
Iowe

Disease Reslstance and Genetics in Honey Bees. To leam bases-physiological, ecological, behavioristic, and genetic, as applicable -- of several characteristics in the honey bee. Zool., Ent. 1332

N. H.

Relation of Honerbee to Horticultural Crops in New Hampshire. To learn (I) effect of colong population and location on distribution of foraging honeybees; (2) pollination requirements for Low-Bush blueberries and apples in New Hampshire. Ent. 114

Oreg.

The Role of Wild Bees and Honer Bees in Crop Production. To learn (1) cause of seedless fruit in pears, (2) reason for fluctuating jleld, (3) optimum pollinator requirements per unit area of orchard, (4) length of time pear floret is receptive to pollination, (5) need of cross pollination by conducting experiments in crossing and selfing. (6) value of attractants in inducing pollination, (7) most advantageous management practices in honey bee colony placement, (8) role of wild bees in pear pollination, (9) range of individual bees, etc.

Ent. 95

Pa.

Control of Nosema Disease, Nosema Apis, In the Honer-Bee. To obtain a method of control of Nosema apis. Ent. 1084

$\mathrm{Pa}$.

The Preparation of Honey For Market. To determine (I) efficiency of existing equipment for processing honey and if necessary to develop new equipment, (2) effect of various processing temperatures on nutritive quality of honey, and (3) develop new honey products for consumer markets.

Zool. and Ent. 1133

S. C. Pollination of Legume Crops. To investigate possible relationship between soil conditions, especially general fertility, $\mathrm{pH}$ level, and content of organic matter, and attractiveness to honey bees of legumes grown on soils varying according to the above conditions.

Ent. 101

Vt.

Marketing Honey in Vermont. (1) Learn type and relative importance of outlets for Vermont 's honey crop. (2) Discover which outlets and marketing practices have proven most profitable in sale of honey. (3) Learn amount and relative importance of gross income derived from sale of honey, beeswax, and bees. (4) Obtain basic data for making a comparison of costs and returns from packing honey in containers of various sizes. Agr. Econ. 62 
II. ECONOMIC ZOOLOGI

\section{Game and Rodents}

Mass.

Animal Damage to Agricultural Crops in Massachusetts. Learn the birds responsible for loss of cultured blueberries and ways of preventing this loss.

For., Wild Life Mgt. 79

Minn. The Effect of Forestry Practices on Ruffed Grouse Population. To (1) determine ruffed grouse populations and the environmental factors affecting them, (2) leam grouse movements and thelr use of varlous forest coverts, (3) relate these two objectives to forestry practices. Ent., Zool. 1732

N. Y.

Studies of Kanmalian Wildlife of Economic Importance in

(Cornell) Now York and the Control of Injurious Species. To obtain fundamental blological data on which to base development of improved methods for control of injurious memmals and the use of beneficial ones.

Conserv. 82 Coop. USDI-FWS

Ohio Ecological Study of the Red-Winged Blackbird as It is Related to the Damage of Crops. (1) Conduct an ecological study of the Red-Winged Blackbird to obtain clues to its control in crops. (2) Study its reaction in plots of corn for clues to its control by use of resistant varieties, planting dates, or various treatments.

int. 171

Oreg. Improvement and Management of Oregon Pastures and Ranges: An Eveluation of Rodent Damage and the Need for Control Messures on Oregon Sagebrush Ranges. To learn (1) influence of rodents and other small mammals on plant succession of selected habitat types on eastern Oregon sagebrush ranges; (2) varlous species and numbers of rodents and other small mammals including rabbits present. (3) Study habits and movements of these and add information to their life histories. (4) Learn need for rodent control measures in improving sagebrush ranges.

Fish and Game Mgt. 160-11 Coop. ARS and USDI-FWS

Pa. Forest Cutting Practices Affecting Deer Foods. To determine quantity of deer browse produced by silvicultural cutting practices.

For., Zool., Ent. 1057 
Utah

The Influence of Small Mammals Upon Range Forage Production and Ava11ability. (1) Learn extent of competition for range forage between rabbits and rodents, and livestock. (2) Evaluate forage consumption of small mammals and resultant effect on range condition. (3) Learn influence of small mammals on natural plant succession.

Range Mgt. 473

W. Va.

Animal Repellents on Hardwood Forest Plantations. To determine (I) extent of wild animal injury to hardwood forest plantations on spoil-banks and in other locations. (2) extent of protection given by chemical repellents, (3) optimum time and frequency of application of repellents, and (4) cost of application of repellents on hardwood plantations of young trees. For. 37

\section{B. Fish and Oysters}

Ala.

The Invertebrate Animals Serving as Food for Fish in Alabama Ponds. Learn species, seasonal cycles of abundance, utilizati on, and ecology of the invertebrate animals that serve as food for pond fish.

Zool., Ent. 425

Ala.

A Surver of the Parasites of Pondfishes in Alabama and Their Control. (1) Leam species, relative abundance and seasonal distribution of protozoan, helminth and arthropod parasites affecting pondfish. (2) Learn effects of parasites on growth and mortality of pondfishes. (3) Develop methods for control of more important fish parasites.

Zool., Ent. 426

Ala.

Chemical Control of Weeds in Ponds. To test (1) effectiveness of commercial and experimental herbicides and algacides on common pond weeds; (2) toxicity of herbicides and algacides to fish and fish food organisms, and their effects on fish production, plankton and bottom organism production; (3) effects of herbicides or algacides on flavor of fish.

Zool., Ent. 427

Mich.

Fish Production and Management in Hatchery Ponds and Naturai Lakes in Michigan. To determine (I) potentialities of small, private waters in production of food and/or cash crop of fish, and determine methods of management of such ponds, and (2) determine possibilities and methods of increasing production of fish in natural lakes.

Fisherles and Wildlife 21 
Mich. The Relation Between Insect Prevalence and the Abundance of Fish in Improved and Unimproved Stream, Pond and Lake Areas. To determine (1) correlation, if any, of numbers and kinds of insects in trout streams to distribution and variation in trout population and factors concerned, and (2) insect fauna, effect of various treatments, fertilization, depth of water, periodical draining, fish population, and other factors on insect population in fish ponds.

Ent. 27

Mich. Farm Fish Pond Management. To (1) estimate production of plants and animals per unit area or volume of water in farm type ponds and natural ponds, (2) determine to what extent fertilization of ponds will increase production of fish food and fish, (3) devise practical management programs for farm ponds, and (4) detect and measure possible detrimental effects of use of fertilizers in fish ponds. Z001. 64

Mich.

Physiologic Response of Aquatic Organisms to Pollutants. To (1) determine physiological cause of death in aquatic animals most susceptible to pollutants, and establish symptoms of sublethal amounts of pollutants, (2) demonstrate and identify responses which may be interesting, but insignificant, for death, as opposed to those which have value as diagnostic symptoms of pollution toxicity, and (3) measure influence of environmental variables on above responses and determine validity of findings in predicting population changes in habitats subjected to pollution.

Phys101., Pharamcol. 122

N. Y.

(Cornell) Studies on the Farm Fish Pond in New Iork State. To determine (1) how valuable as fish producers, farm ponds may be under New York conditions; (2) factors which favor or hinder the production of raluable fishes in such ponds; and (3) to test and demonstrate successful pond fish management methods.

Conserv. 80 Coop. FS and USDI

Oreg. A Study of "Nativen Oyster, Ostrea Lurida. Farming in Oregon, as a Supplementary Agricultural Enterpriso. To determine (1) present and past status of oyster farming as a supplementary agricultural enterprise; (2) available unproductive lands which may be developed into oyster farms; (3) methods for preparing tidal lands for oyster farming; (4) malntenance of prepared lands; (5) costs of preparation; and (6) amount of land required for an oconamic part-time farming unit.

Fish and Game $\mathrm{Mgt}$. 14 
Oreg.

Determination of Fish Species and Management Practices Best Suited to Farm Ponds in Oregon. (1) Ascertain present pond management practices in Oregon. (2) Formulate suitable management practices for ponds built for fish production (3) Study possibility of using irrigation and stockwatering ponds for fish.

Fish and Game Mgt. 294 Coop. FES 


\section{Regional Research}

NC-22 Investigations of Oak Wilt. To gain on a region wide basis, essential information concerning the fungus causing the oak wilt disease, factors responsible for spread, including possible insect vectors, information on the longevity of the fungus, the effect of the fungus on wood killed by the disease and a possible antibiotic relationship of associated wood fungi on the oak wilt organism. To formulate control procedures and to develop, if possible, silvicultural practices that will permit contimious wood lot production even though the disease is present. Cooperating stations and agencies: Iowa I-D*, Ohio I-G, Cook County Forest Preserve Dist., III. Nat. Hist. Serv., Nat. Oak Wilt Research Comm, and ARS.

WM-16

Maintaining Grain Marketability By Insect Control in Storage. To determine the stored product insects of economic importance in the Western Region and the ecclogical factors responsible for their presence or abundance under both dry and humid conditions. To evaluate the efficacy of grain protectants, residual sprays and fumigants under laboratory and field conditions. Cooperating stations and agencies: Ariz., Calif., Colo., Idaho, Oreg., Wash., (all contributing projects in I-E), and AMS.

Biology and Control of Certain Insects Affecting Forest Trees and Unfinished Forest Products in the South. To evaluate damage caused by certain forest insects and study their life histories and habits. To study the effect of environmental factors on the biology of these insects and develop control measures applicable to nurserles, forests, woodlots and unfinished wood products.

Cooperating stations and agencies: Ala. I-D, Miss. I-D, FS.

*The Roman numeral (and capital letter) refer to the location in the summary of the contributing project title and objectives. 
LIST OF COMPILATIONS OF FEDERAL-GRANT RESEARCH PROJECTS AT STATE AGRICULTURAL EXPERIMENT STATIONS

ARS-23-8:
Part : Subject-Matter Area
Numbers :

Agricultural Chemistry

2

Agricultural Economics

3

4

5

6

7

8

9

Field Crops

Food Science \& Technology

Forage Crops, Pastures

\& Ranges

11 Forestry
Agricultural Chemistry

a. Prices, Incomes, \& General' Studies of Commodities \& Industries

b. Farm Management

c. Land Economics

d. Farm Finance \& Taxation

a. Land \& Water Use \& Devêlopment

b. Power Machinery \& Equipment

c. Farm Structures \& Materials

a. Beef Cattle

b. Sheep \& Goats

c. Swine

Dairy Cattle

Dairy Technology

a. Field Crop Insects

b. Fruit, Nut \& Vegetable Insects

c. Miscellaneous Insects \& Economic Zoology

d. Insecticides

a. Cereal Crops

b. Oil, Fiber, Tobacco \& Sugar Crops

a. Food Chemistry, Microbiology, Sanitation \& Public Health

b. Food Engineering, Processing, Product and Process Development, Utilization and Waste Disposal

c. Food Quality \& Standards, Acceptance, Preference, \& Marketing

Forage Crops, Pastures

\& Ranges

Forestry 


\begin{tabular}{|c|c|c|}
\hline $\begin{array}{c}\text { ARS-23-8: } \\
\text { Part : } \\
\text { Numbers : }\end{array}$ & Subject-Matter Area & Title of Section \\
\hline 12 & Fruits \& Nuts & Fruits \& Nuts \\
\hline 13 & Home Economics & $\begin{array}{l}\text { a. Human Nutrition } \\
\text { b. Housing } \\
\text { c. Clothing \& Textiles } \\
\text { d. Foods-Consumer Quality } \\
\text { \& Utilization } \\
\text { e. Household Economics \& } \\
\text { Management }\end{array}$ \\
\hline 14 & $\begin{array}{l}\text { Economics of } \\
\text { Marketing }\end{array}$ & $\begin{array}{l}\text { a. Field Crops } \\
\text { b. Fruits \& Vegetables } \\
\text { c. Livestock, Meats \& Wool } \\
\text { d. Dairy Products } \\
\text { e. Poultry \& Poultry Products } \\
\text { f. Forest Products \& Ornamental } \\
\text { \& Drug Plants } \\
\text { g. Cross-Commodity \& Functional } \\
\text { Studies }\end{array}$ \\
\hline 15 & Meteorology & Meteorology \\
\hline 16 & Ornamental \& Drug Plants & Ornamental \& Drug Plants \\
\hline 17 & $\begin{array}{l}\text { Plant Pathology } \\
\text { \& Bacteriology }\end{array}$ & $\begin{array}{l}\text { a. Plant Pathology, Botany, \& } \\
\text { Diseases of Miscellaneous } \\
\text { Crops } \\
\text { b. Diseases of Field Crops } \\
\text { c. Diseases of Fruit Crops } \\
\text { d. Diseases of Vegetable Crops }\end{array}$ \\
\hline 18 & $\begin{array}{l}\text { Plant Physiology } \\
\text { \& Nutrition }\end{array}$ & Plant Physiology \& Nutrition \\
\hline 19 & Poultry Industry & Poultry Industry \\
\hline 20 & Rural Sociology & Rural Life Studies \\
\hline 21 & Soils & $\begin{array}{l}\text { a. Soil Chemistry \& Microbiology } \\
\text { b. Soil Fertility, Management \& } \\
\text { Soil-Plant Relationships } \\
\text { c. Soil Physical Properties, } \\
\text { Conservation \& Classification }\end{array}$ \\
\hline 22 & Vegetables & $\begin{array}{l}\text { a. Vegetable Crops } \\
\text { b. Potatoes }\end{array}$ \\
\hline 23 & Veterinary Science & Veterinary Science \\
\hline 24 & Weeds & Weed Control \\
\hline
\end{tabular}



